\title{
AFRICANISMO NUEVO Y VIEJO EN ESPAÑA: UN COLOQUIO EN LA U. N. E. D. DE MADRID
}

Míkel dE Epalza

Del 11 al 13 de abril de 1983 tuvo lugar en la sede madrileña de la Universidad Nacional de Educación a Distancia un Coloquio sobre "Relaciones entre España y Africa». Su planteamiento desborda y supera lo que podría ser un simple encuentro de especialistas o la simple lista de conferenciantes. Marca, aunque sea con algunas limitaciones, la consagración de unas nuevas líneas de estudio de la historia de las relaciones hispanoafricanas, en época contemporánea.

En efecto, el Coloquio que fue inaugurado por la Rectora de la UNED y presidido por el Profesor Tusell, Jefe del Departamento de Historia Contemporánea de la UNED, fue organizado por el profesor Víctor Morales Lezcano, autor de numerosos trabajos históricos sobre la estrategia de las Islas Canarias y el Estrecho de Gibraltar y sobre todo, sobre el período colonial español en Marruecos, tema en el que es el investigador científico español más riguroso. Representaba en el Coloquio a la historiografía de las relaciones hispano-magrebies de mayor porvenir, la que se basa en documentación archivística y en escritos de toda índole, pero leídos con un profundo espiritu crítico, políticamente crítico. Ejercicio metodológico éste muy difícil de realizar para el período colonial español, donde los móviles económicos, militares y políticos se cubrian con consideraciones patrióticas y con un racismo patente, frente a los africanos en general y a los árabes del Mágreb en particular. 
Junto a esta tendencia de la historiografía política, el profesor Juan Bautista Vilar, de la Universidad de Murcia, con su ponencia sobre "Corrientes migratorias en el Norte de Africa: los españoles en Argelia (1830-1914)" que desbordó ampliamente el territorio y el período del título, representa también el rigor metodológico y documental en la evaluación de los fenómenos sociales. Una inmensa documentación, en los archivos y en la Sección Africa de la Biblioteca Nacional de Madrid, esperan estudios semejantes de historia hispano-africana.

Este mismo estudio riguroso, pero con métodos antropológicos o etnológicos, se manifestaron en las ponencias de Julio Caro Baroja, de la Real Academia de la Historia, sobre "Visión antropológica del Sáhara en 1952", que evidentemente corresponde a una situación y a una visión de hace más de 30 años, y del antropólogo norteamericano instalado en España David $M$. Hart, "Los beréberes del Rif", autor de imprescindibles estudios sobre las etnias rifeñas en el siglo $X X$, especialmente las que apoyaron al jefe marroquí Abdelkrim Al-Jattabi. También aquí la visión "descolonizada» de la realidad y de la historia magrebí reciente suponen un paso adelante importante frente a la producción escrita de época colonial, cuyos viejos representantes sólo estuvieron presentes en el coloquio en espíritu, para rechazarlos explícita o silenciosamente. Un hermoso monumento - monumento fúnebre - les acaba de ser merecidamente consagrado por el Ministerio español de Asuntos Exteriores en el libro de Rodolfo Gil Grimau, Aproximación a una bibliografía española sobre el Norte de Africa (1850-1980), en el que se recogen 16.122 títulos españoles sobre el Mágreb y especialmente Marruecos, en su mayoría de textos escritos con el espíritu del viejo africanismo colonial.

Este espíritu, que podia haber estado representado por el general Cola Alberich, presente en el Coloquio pero muy discreto, lo fue en el último día por un participante que no pudo menos de manifestar su desaprobación de la forma crítica con la que se trataba la colonización española en el Golfo de Guinea: Enrique Pariente "Orígenes del colonialismo español en los territorios del golfo de Guinea"; Teresa Pereira "Aproximaciones al estudio del colonialismo español en los territorios del golfo de 
Guinea, durante el primer cuarto del siglo XX"; Hipólito de la Torre "El colonialismo portugués en el Africa subsahariana" (una comparación muy enriquecedora); y Donato Ndongo «El guineano en la sociedad colonial y postcolonial". Con esta última ponencia se cumplia también con una norma muy provechosa, que poco a poco va introduciéndose en esta clase de encuentros científicos: la de dejar hablar también a los súbditos de los países que se estudian, con tal evidentemente de que sean expertos científicos en los temas estudiados. Lo mismo se hizo con Marruecos en la persona de la hispanista de la Universidad de Rabat, Ravea Hatim, que presentó una visión al mismo tiempo objetiva, simpática y crítica de su tema "Marruecos en la novela española del siglo XX". Fue otro aspecto, el literario, de gran trascendencia en la opinión pública y al mismo tiempo reflejo de ella, de las multiformes relaciones hispano-marroquíes, sobre todo en la primera mitad del siglo XX.

A estos representantes de las nuevas corrientes historiográficas del africanismo ha sabido también integrar el profesor Víctor Morales Lezcano a los arabistas, representados en el Coloquio por el especialista del XVIII hispano-marroquí Mariano Arribas Palau y por Míkel de Epalza que presentó su ponencia sobre "Los moriscos en el contexto de las corrientes migratorias en el norte de Africa". En las discusiones de esta ponencia se comentó la innovación que supuso en los años 70 el que arabistas y africanistas españoles se reunieran en la revista Almenara (desaparecida después de 10 volúmenes) para estudiar el mundo árabe moderno y especialmente el mundo magrebí, terreno anteriormente poco frecuentado por los historiadores que pueden utilizar las fuentes árabes.

Todas estas corrientes, presentes en el Coloquio y deseosas de proseguir en una colaboración que lleva ya años dándose y que puede mirar el porvenir con sosiego, no dejaban de advertir algunas ausencias: algunos profesores de las Facultades de Historia y Ciencias Políticas de la Universidad Autónoma de Madrid, que dirigen tesis y trabajos serios sobre política hispanomagrebí; del Departamento de Arabe de la Universidad Autónoma de Madrid, tradicionalmente interesados en temas árabes modernos, que pueden a veces tratar con seriedad (Barnabé Ló- 
pez Garcia, también profesor en la Universidad de Fez); más especialistas marroquíes en la colonización franco-española del siglo XX. Pero en este Coloquio madrileño se pusieron las bases y el núcleo de futuros encuentros que jalonen los progresos historiográficos del nuevo africanismo español. 